\title{
Venous Communication Between the Right and Left Kidneys: A Rare Anatomic Variation
}

\author{
Comunicación Venosa entre los Riñones Derecho e Izquierdo: Una Rara Variación Anatómica
}

\author{
W. J. Favaro; T. D. Santos \& V. H. A. Cagnon
}

FAVARO, W. J.; SANTOS, T. D. \& CAGNON, V. H. A. Venous communication between the right and left kidneys: A rare anatomic variation. Int. J. Morphol., 27(1):117-120, 2009.

SUMMARY: Renal vascular anatomic variations, especially of the renal arteries, have been observed in about 20-30\% of cases, which are very often verified in the left antimere. These variations showed two or three renal arteries stemming directly from the aorta. These anatomic variations have been considered extremely important risk factors in surgical proceedings by different authors. The dissection of a cadaver showed an uncommon venous feature in addition to renal artery variation, specially, in the left antimere. A direct venous communication between left and right kidneys was verified without there being any relation to the inferior cava vein or common iliac veins. Thus, the knowledge of blood vessel anatomic variation is an important element to improve surgical techniques as well as to provide precise analyses of urological and radiological proceedings in different renal diseases. Specially, taking into consideration that hard traction of the renal pedicle could rupture the vessels, leading to lethal hemorrhaging.

KEY WORDS: Renal vessels; Anatomic variations; Anatomic dissection.

\section{INTRODUCTION}

Renal vascular anatomic variations have been characterized by different authors, and the prevalence of multiple vessels occurs in about $20-50 \%$ of cases (Testut \& Latarjet, 1959; Isoda et al., 2002; Bordei et al., 2004; Sampaio, 2007). Renal artery multiplicities, especially in the left antimere, were compared to other same sized arteries in the body. Also, Harrison et al. (1978), Awojobi et al. (1983), Kinnunen et al. (1985) and Sampaio verified that this renal artery distribution is more frequent than the occurrence of multiple veins. According to various authors, renal arterial variations are characterized by two or three arteries stemming directly from the aorta (Poirier \& Charpy, 1920; Testut \& Latarjet; Bordei et al.; Sampaio). On the other hand, renal vein variations represent about $18 \%$ of cases, occurring notwithstanding arterial variations (Poirier \& Charpy; Testut \& Latarjet). Nowadays, advances in urological surgery as well as in radiological interventional procedures have pointed towards a large interest in renal vessels anatomy, because the complete understanding of this anatomy is essential for the safe and efficient performance of these procedures (Khamanarong et al., 2004).
Thus, the anatomic variation of renal vessels is one of the most important determining factors for precise clinical proceedings, indicating the fundamental need of knowledge to avoid failure in this field.

\section{CASE REPORT}

The abdomen of a 40 year old white male cadaver was topographically dissected. After that, the kidney blood vessels were separated from adjacent tissues by means of anatomic pincers and number 15 bistouries. Later, length and diameter measurements of the vessels were taken, using a caliper ruler (Mitutoyo, Tokyo-Japan) (Table I).

A rare venous variation was characterized, showing a venous communication between the left and the right kidneys, without relation to either inferior cava vein or common iliac veins. This venous variation was $17 \mathrm{~cm}$ long and $4.5 \mathrm{~cm}$ in diameter (Fig. 1). In addition, there were four 
other variations of these veins. In two of these four variations, the left renal veins drained to the left common iliac vein and the other two left veins drained to the inferior cava vein.

Regarding the arterial distribution, it was observed that four arteries originated directly from the aorta, three of them supplying the left kidney and the other one, the right kidney. Also, other two arteries originated from the common iliac artery, where one of them supplied the left kidney and the other one, the right one. Moreover, there is a last artery, originated from the aorta bifurcation supplying the left kidney (Fig. 1).
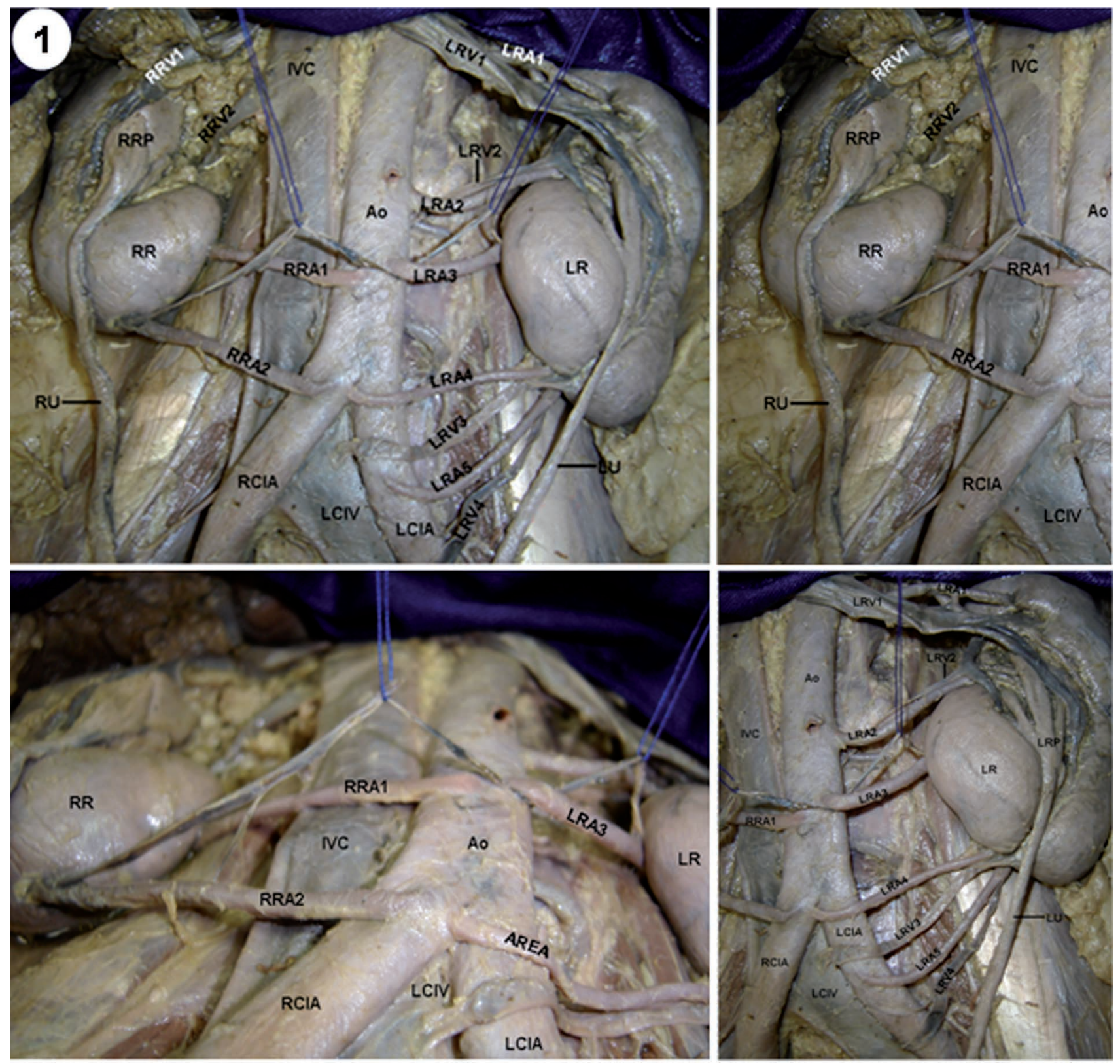

Fig. 1. Ao - Abdominal Aorta, IVC - Inferior vein cava, LCIA - Left common iliac artery, LCIV - Left common iliac vein, LRP - Left renal pelvis, LR - Left kidney, LRA1, 2, 3, 4, 5 - Left renal artery, LRP - Left renal pelvis, LRV 1, 2, 3, 4 - Left renal vein, LU - Left ureter, RCIA - Right common iliac artery, RR - Right kidney, RRA1, 2 - Right renal artery, RRP - Right renal pelvis, RU - Right ureter, RRV1, 2 - Right renal vein. Rare venous variation between left and right kidney (surgical wires). Magnification $2 X$. 
Table I. Length $(\mathrm{cm})$ and diameter $(\mathrm{mm})$ of the kidney artery and vein from left and right antimeres. LRA - Left kidney artery, RRA - Right kidney artery, LRV - Left kidney vein, RRV - Right kidney vein.

\begin{tabular}{ccc}
\hline \multicolumn{3}{c}{ Measurements } \\
Renal vessels & Length & Diameter \\
\hline LRA 1 & 6.0 & 5.0 \\
LRA 2 & 6.5 & 5.2 \\
LRA 3 & 4.5 & 5.0 \\
LRA 4 & 7.5 & 4.5 \\
LRA 5 & 8.0 & 5.1 \\
RRA 1 & 6.0 & 5.3 \\
RRA 2 & 9.0 & 5.6 \\
LKV 1 & 16.0 & 9.0 \\
LRV 2 & 7.5 & 6.0 \\
LRV 3 & 6.2 & 4.5 \\
LRV 4 & 8.0 & 4.3 \\
RRV 1 & 7.6 & 7.8 \\
RRV 2 & 5.2 & 6.4 \\
\hline
\end{tabular}

\section{DISCUSSION}

This work confirmed that both venous and arterial variations are more frequent in the left antimere than in the right one. Moreover, the identification of the venous communication between the left and right kidneys characterized a rare and relevant venous feature, considering the diameter and length of this vessel which could be essential characteristic in the surgical proceedings. Specialized literature confirmed that venous distribution, similar to the one shown in the present case, is unusual (Sappey, 1869; Poirier \& Charpy; Chiarugi, 1924; Testut \& Latarjet).

Various authors demonstrated that each multiple renal vessel is a terminal vessel, whereas any lesion can cause segmental ischemia, hemorrhaging, lack of kidney parenchyma and occasional arterial hypertension (Kinnunen et al.; Sampaio).

According to Testut \& Latarjet, the renal vein variations are probably related to the development of the inferior cava vein and they are not associated to arterial variations. Thus, it could be suggested that both arterial and venous variations come from specific embryological disturbance, which would persevere embryological renal vessels that should disappear in normal development.

Finally, taking into consideration the anatomical variation multiples verified in these results, it could be concluded that the identification of anatomic variations from renal vessels showed another possibility of venous and arterial distribution, which could have a critical role for clinical proceedings, considering the anatomic feature and the variation complexity as a definitive element to avoid renal transplant complications and unsuccessful renal trauma repairs in oncological and conserving surgeries. Nevertheless, the anatomic characteristics could allow more precise urological and radiological analyses.

ACKNOWLEDGMENT: Department of Anatomy/Institute of Biology/ University of Campinas.

FAVARO, W. J.; SANTOS, T. D. \& CAGNON, V. H. A. Comunicación venosa entre los riñones derecho e izquierdo: Una rara variación anatómica. Int. J. Morphol., 27(1):117-120, 2009.

RESUMEN: Se han observado variaciones anatómicas vasculares renales, especialmente de las arterias renales, en una frecuencia alrededor del 20 a $30 \%$ de los casos, cuya incidencia se verifica a menudo en el antímero izquierdo. En estas variaciones, de acuerdo con lo que se notó, dos o tres arterias renales provenían directamente de la aorta. Distintos autores han considerado que estas variaciones anatómicas son factores de riesgo extremadamente importantes en los procedimientos quirúrgicos. En esta investigación, por medio de la disección de un cadáver, se observó una característica venosa rara, además de la variación de la arteria renal, especialmente en el antímero izquierdo. Se verificó una comunicación venosa directa entre los riñones izquierdo y derecho, pese al hecho que no sea común cualquier relación con la vena cava inferior o las venas ilíacas comunes. Así, el conocimiento de la variación anatómica del vaso sanguíneo es un elemento importante para implementar técnicas quirúrgicas, así como proporcionar análisis exactos de procedimientos urológicos y radiológicos en diversas enfermedades renales, pues se debe considerar además que la tracción dura del pedículo renal podría romper los vasos y ocasionar una hemorragia mortal.

PALABRAS CLAVE: Vasos renales; Variaciones anatómicas; Disección anatómica.

\section{REFERENCES}

Awojobi, O. A.; Ogunbiyi, O. A. \& Nkposong, E. O. Unusual relationship of multiple renal arteries. Urology, 21(2):205-6, 1983.

Bordei, P.; Sapte, E. \& Iliescu, D. Double renal arteries originating from the aorta. Surg. Radiol. Anat., 26(6):474-9, 2004.

Chiarugi, G. Istituzioni di anatomia dell'uomo. Milano, Società Editrice Libraria, 1924. 
Harrison, L. H. Jr.; Flye, M. W. \& Seigler, H. F. Incidence of anatomical variants in renal vasculature in the presence of normal renal function. Ann. Surg., 188(1):83-9, 1978.

Isoda, H.; Saitoh, M.; Asakura, T.; Akai, M.; Itagaki, Y.; HaKawa, S. K.; Harima, K. \& Sawada, S. An unusual arterial supply of the kidney from the opposite renal artery. Comput. Med. Imaging. Graph., 26(5):353-5, 2002.

Khamanarong, K.; Prachaney, P.; Utraravichien, A.; TongUn, T. \& Sripaoraya, K. Anatomy of renal arterial supply. Clin. Anat., 17(4):334-6, 2004.

Kinnunen, J.; Tötterman, S. \& Tervahartiala, P. Ten renal arteries. Eur. J. Radiol., 5(4):300-1, 1985.

Poirier, P. \& Charpy, A. Traité d'anatomie humaine. Paris, Masson, 1920. V. 5. Pp. 88-110.

Sampaio, F. J. B. Anatomia renal para urologia. Rio de Janeiro, Gráfica e Editora Prensa, 2007. pp. 73-81.

Sappey, C. Traité d'anatomie descriptive. Paris, Adrien Delahaye et Émile Lecrosnier Editeurs, 1869.

Testut, L. \& Latarjet, A. Tratado de Anatomía Humana. Barcelona, Salvat, 1959. pp. 871-87.
Correspondence to:

Valéria H. A. Cagnon PhD.

Department of Anatomy

Institute of Biology

University of Campinas (UNICAMP)

P.O. Box 6109,

13083-865

Campinas

SP, BRAZIL

Telephone: +(55) 19-3521-6102.

Fax: +(55) 19-3289-3124.

Email: quitete@unicamp.br

Received: 05-09-2008

Accepted: 12-11-2008 